LAW RENCE LIVERMORE N A T IO N A L LABORATORY

J. Woollett

January 26, 2006 
This document was prepared as an account of work sponsored by an agency of the United States Government. Neither the United States Government nor the University of California nor any of their employees, makes any warranty, express or implied, or assumes any legal liability or responsibility for the accuracy, completeness, or usefulness of any information, apparatus, product, or process disclosed, or represents that its use would not infringe privately owned rights. Reference herein to any specific commercial product, process, or service by trade name, trademark, manufacturer, or otherwise, does not necessarily constitute or imply its endorsement, recommendation, or favoring by the United States Government or the University of California. The views and opinions of authors expressed herein do not necessarily state or reflect those of the United States Government or the University of California, and shall not be used for advertising or product endorsement purposes.

This work was performed under the auspices of the U.S. Department of Energy by University of California, Lawrence Livermore National Laboratory under Contract W-7405-Eng-48. 


\section{LLNL 10(a)(1)(A) Annual Report (TE-053672-2)--2005}

\section{Introduction}

This report summarizes research related to Lawrence Livermore National Laboratory's (LLNL) Experimental Test Site, Site 300 (S300), located within Alameda and San Joaquin Counties (Figure 1) and conducted under the 10(a)(1)(A) (Recovery) permit TE-053672-2. This property is held in ownership by the U.S. Department of Energy/National Nuclear Security Administration (NNSA). The 2005 Recovery research at S300 involved fieldwork associated with only two species: Alameda whipsnake (Masticophis lateralis euryxanthus) and the California red-legged frog (Rana aurora draytonii) (RLF). Note: the whipsnake subspecies existing at $\mathrm{S} 300$ shows taxonomic variation (generally $50 \%$ chaparral whipsnake [Masticophis lateralis lateralis] traits) when compared to the Alameda whipsnake (Riemer 1954) and therefore it will be referred to as "California whipsnake (Masticophis lateralis)" (CWS) for classification purposes in this report (Swaim 2004).

\section{Background}

A research project (Biological Opinion \#1-1-02-F-0064) investigating the direct effects (fatality/harm) and indirect impacts (habitat alteration) of prescribed burning on the Alameda whipsnake was permitted by the U.S. Fish and Wildlife Service (Service), Sacramento Office, in the spring of 2002. Several different public resource management agencies were approved by the Service to implement recovery-oriented (fuels treatment) studies associated with this research plan. LLNL's proposed six-year study was initiated in 2002 and is anticipated to conclude in 2007. Results reflected in this report apply to information gathered during the first four years of the project; because of the low CWS sample size collected onsite, long-term conservation-related measures for CWS are not yet evident from the study results.

Past recovery reports for CWS stating annual findings and the preliminary results at S300 have been previously documented by the Principal Investigator, Karen Swaim (Swaim Biological Consulting). Please review these reports, annual LLNL reports, and the original research proposal for a more detailed description of the study rationale, design, and scope (Swaim 2002a, Swaim 2002b, Swaim 2003, Swaim 2004).

The RLF research (Biological Opinion\# 1-1-02-F-0062) involves translocating individuals from a wetland location that has been receiving artificial (potable) water discharges for the last 15-20 years. This surface discharge is being terminated, and RLF's that occupy the adjacent wetland are being moved to an enhanced wetland area further downstream (engineered pools in a pre-existing perennial drainage) in an area called "Mid-Elk Ravine." 
Although the bulk of RLF's will likely be moved in the spring of 2006, two male (and three young-of-the-year) RLF's were translocated in December as a part of the early phase of the project, and the information relevant to these individuals will be presented here.

\section{Methodology}

For a complete discussion of the methodology associated with the CWS research project see "Research Proposal: Effects of Prescribed Burns on the Alameda Whipsnake" (Swaim 2002a, Attachment I). Trapping and marking individual CWS in both the Treatment (Burn) and Control areas continued in 2005 at S300 (Figure 2). Two changes to the research design methods were implemented this year. Based on the cumulative results from the previous three years, the Service Recovery Program Branch Coordinator (January 2005) authorized LLNL to curtail trapping in the fall based on the low trap success numbers occurring during this period. Additionally, because Spring results indicated a low variance in the number of CWS trapped even with a wide range in trap-effort (trap days varied between 36 and 62 days 2002-2005; average number of individuals did not change), the Service Recovery Program Branch coordinator released the requirement that LLNL trap on every weekend during the spring study period.

Methods for RLF tagging and translocation are covered in the attached document (Mitigation and Monitoring Report, Attachment II). LLNL is currently receiving training from Trish Tatarian (Greg and Trish Tatarian, Wildlife Research Associates, 1119 Burbank Ave., Santa Rosa, CA 95407) on PIT tagging and belttransmittering of RLFs.

\section{$\underline{\text { Results }}$}

California Whipsnakes

Spring trapping resulted in the capture of 5 new CWS individuals (4 males, 1 female) (Figure 3 ) and the recapture of 3 previously tagged CWS individuals (2 males, 1 female) (Figure 4). Recaptured CWS \#1 is the only snake in this study that has been captured in both the Treatment and Control sites and was trapped again in the Burn area in 2005. Individual numbers and total numbers of snakes captured per trap day are reflected in Figures 5 and 6 showing that slightly higher CWS captures occur in the control area overtime. The diminishment of snake captures by year, season, and in the burn area are represented in Table 1.

\section{California Red-legged Frogs}

Figure 7 displays an aerial photograph of the RLF translocation project area with the man-made wetland (B865) and the enhanced wetland where the frogs have been/will be subsequently moved to in Mid-Elk Ravine. 
The five frogs translocated on December 12, 2005 were composed of two males (first year Adult, 85mm; Adult, 95mm) and three young-of-the-year. Both males received PIT tags and transmitters. Both males have remained within the general area of the pool since the translocation process. The transmitters are expected to last until the beginning of April and location monitoring is ongoing (weekly). Additionally, both male frogs have been observed since December 12 and the belt transmitters show no sign of abrasion or injury to the animal to date. 


\section{Discussion/Conclusion}

Low sample size this year (5 new captures; 3 recaptures) plus similar annual sample sizes between 2002-2004 make it difficult to correlate any trends or findings of significance for spring trapping of CWS. As previously discussed, fall trapping was not performed this year and no discussion is included for that season. Overall, new snake captures dropped by a few individuals in both the Control and Burn plots in 2005. The drop in number in the Burn area appears slightly greater than in the Control area, but the low total number of captures make these observations difficult to interpret. The Control site appears to have consistently captured greater numbers of CWS since the inception of the research, possibly because this area of scrub is larger in size (can support more individuals presumably) than the outlying scrub patch of the Burn site.

Despite 2005 being the fourth year of research, recapture numbers remain low (34 individuals), but these few animals show strong site fidelity to the respective areas where originally trapped. CWS \#1, recaptured in the burn area, was utilizing the one portion of the treatment area that was not burned completely during the 2003 treatment. This supports the hypothesized value of the "burn mosaic" concept to recolonization of a burned site and foraging behavior by CWS. Potentially, burned areas that maintain some islands of structure for the snakes to utilize as the area recovers offer locations for shelter, foraging or thermoregulation activities that may not be available in the burned area. CWS \#1 was the only recapture this year from the Burn area. Further years of trapping may provide additional insight into this phenomenon as more snakes are recaptured (Figure 5).

The translocation of the five RLFs in December appears to offer a potential for future success. Both males with transmitters have stayed within the enhanced areas of wetland designed for them and have not returned "home" to the B865 area (Rathbun and Schneider 2001) despite passing wet weather systems that have offered them opportunity for movements. No other adult RLFs have been observed at the two new pools and possibly this has allowed the translocated animals to find a less competitive environment to settle into. Further results are anticipated in 2006 to support or negate these preliminary findings. 


\section{REFERENCES}

Rathbun, Galen B. and Julie Schneider. 2001. Translocation of California Redlegged frogs (Rana aurora draytonii). Wildlife Society Bulletin 2001, 29(4): 1300-1303.

Riemer, W.J. 1954. A new subspecies of the snake, Masticophis lateralis, from California. Copeia 1954 (1) 45-48.

Swaim Biological Consulting. 2002a. Research Proposal: Effects of Prescribed Burns on the Alameda Whipsnake (Masticophis lateralis euryxanthus). Prepared for H. Bell, Research Branch, Endangered Species Division, USFWS, Sacramento Office.

Swaim Biological Consulting. 2002b. Draft-Results of Baseline (pre-burn) Trapping Survey for the Alameda Whipsnake (Masticophis lateralis euryxanthus) at Lawrence Livermore National Laboratory's S300, Alameda and San Joaquin Counties, Prepared for Lawrence Livermore National Laboratory, Site 300, 16pp.

Swaim Biological Consulting. 2003. Draft Annual Report-Results of Baseline (pre-burn) Trapping Survey for the Alameda Whipsnake (Masticophis lateralis euryxanthus) at Lawrence Livermore National Laboratory's S300, Alameda and San Joaquin Counties, Prepared for Lawrence Livermore National Laboratory, Site 300, 47 pp.

Swaim Biological Consulting. 2004. Annual Report--Results of Baseline (preburn) Trapping Survey for the Alameda Whipsnake (Masticophis lateralis euryxanthus) at Lawrence Livermore National Laboratory's S300, Alameda and San Joaquin Counties, Prepared for Lawrence Livermore National Laboratory, Site 300, 25 pp. 
Table 1. Number of California whipsnakes captured over the entire study from 2002 to 2004.

\begin{tabular}{|c|c|c|c|c|c|c|}
\hline & Year & $\begin{array}{c}\text { New } \\
\text { Snakes }\end{array}$ & $\begin{array}{l}\text { Number of } \\
\text { Individuals }\end{array}$ & $\begin{array}{c}\text { Recaptures } \\
\text { from Previous } \\
\text { Season }\end{array}$ & $\begin{array}{c}\text { Total } \\
\text { Captures }\end{array}$ & Days \\
\hline Control & $\begin{array}{l}2002 \\
2003 \\
2004 \\
2005\end{array}$ & $\begin{array}{l}6 \\
6 \\
3 \\
4\end{array}$ & $\begin{array}{l}6 \\
7 \\
5 \\
6\end{array}$ & $\begin{array}{l}0 \\
1 \\
2 \\
2\end{array}$ & $\begin{array}{l}8 \\
7 \\
8 \\
7\end{array}$ & $\begin{array}{l}62 \\
36 \\
51 \\
37 \\
\end{array}$ \\
\hline Burn & $\begin{array}{l}2002 \\
2003 \\
2004 \\
2005\end{array}$ & $\begin{array}{l}5 \\
1 \\
2 \\
1\end{array}$ & $\begin{array}{l}6 \\
4 \\
4 \\
2\end{array}$ & $\begin{array}{l}1 \\
3 \\
2 \\
1\end{array}$ & $\begin{array}{c}11 \\
5 \\
6 \\
2\end{array}$ & $\begin{array}{l}62 \\
36 \\
51 \\
37\end{array}$ \\
\hline
\end{tabular}

\section{Fall Trapping Period}

\begin{tabular}{|c|c|c|c|c|c|c|c|c|}
\hline & Year & $\begin{array}{c}\text { New } \\
\text { Snakes }\end{array}$ & $\begin{array}{l}\text { Number of } \\
\text { Individuals }\end{array}$ & $\begin{array}{c}\text { Recaptures } \\
\text { from Previous } \\
\text { Season }\end{array}$ & $\begin{array}{c}\text { Total } \\
\text { Captures } \\
\end{array}$ & $\begin{array}{c}\text { Adult } \\
\text { New Snakes }\end{array}$ & $\begin{array}{c}\text { Adult } \\
\text { Total Captures }\end{array}$ & Days \\
\hline \multirow[t]{3}{*}{ Control } & 2002 & 3 & 3 & 0 & 4 & 0 & 1 & 34 \\
\hline & 2003 & 1 & 1 & 0 & 1 & 1 & 1 & 33 \\
\hline & 2004 & 1 & 1 & 0 & 1 & 0 & 0 & 32 \\
\hline \multirow[t]{3}{*}{ Burn } & 2002 & 3 & 3 & 0 & 5 & 1 & 2 & 34 \\
\hline & 2003 & 0 & $\mathbf{0}$ & 0 & 0 & 0 & 0 & 33 \\
\hline & 2004 & 0 & $\mathbf{0}$ & 0 & 0 & 0 & 0 & 32 \\
\hline
\end{tabular}

Notes:

- Number of Individuals $=$ New Snakes + Recaptures from Previous Season (does not include multiple captures of new or recaptured snakes within the trapping period)

- Total Captures $=$ New Snakes + Recaptures from Previous Season + Recaptures within the trapping season

- Trapping period = the total duration of trapping in the spring season or the total duration of trapping during the fall season

- A trap day includes each full day (24 hours) from opening the traps in the morning until the next morning. If traps were closed in the afternoon after trap checks were completed, but before the entire 24-hour trap day was completed, that day was counted as $1 / 2$ trap day. 


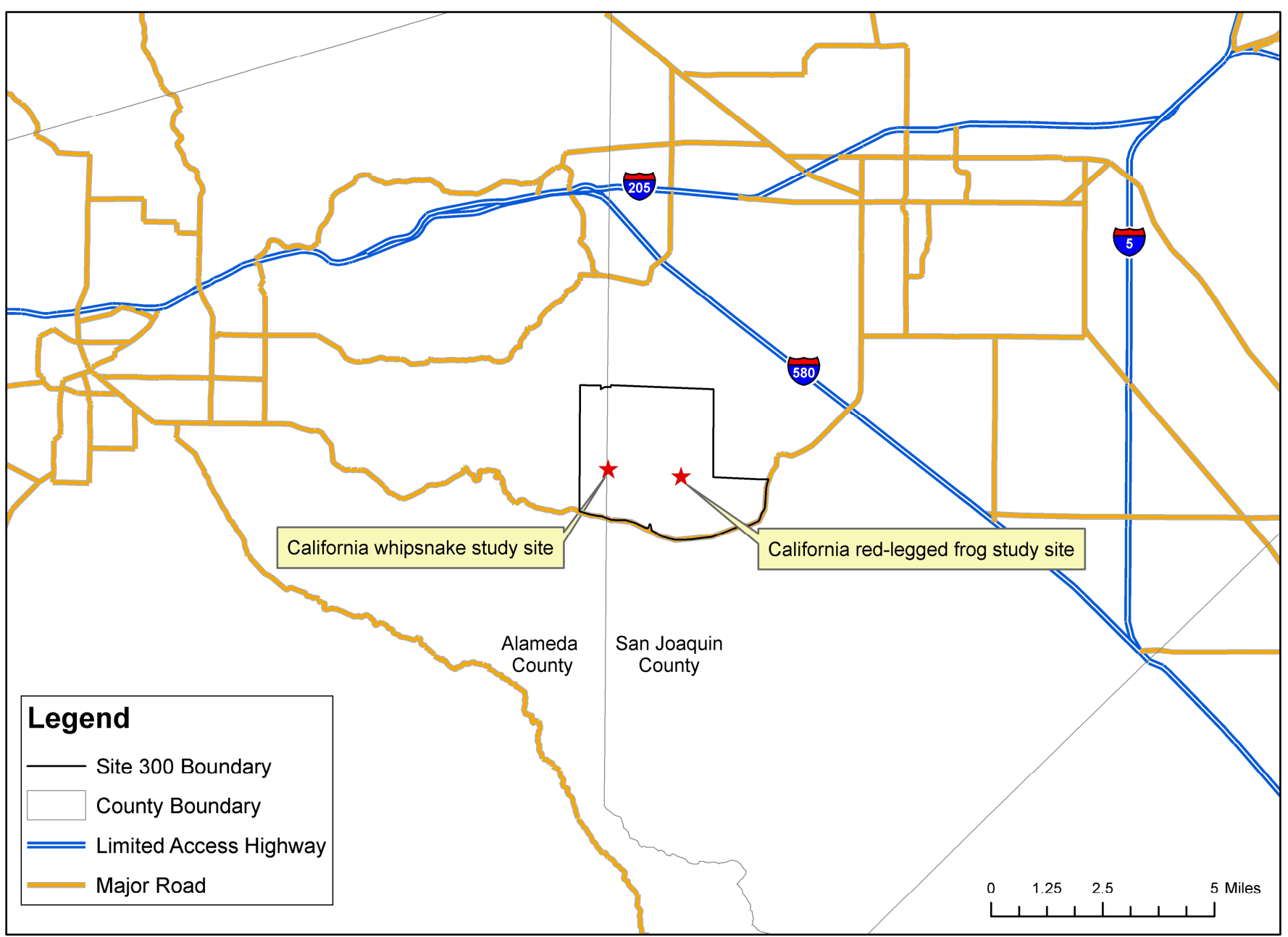

Figure 1. Regional location of California whipsnake and California red-legged frog study sites. 


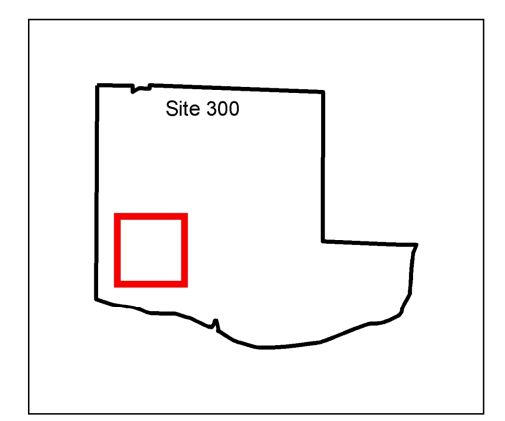

\section{Legend}

2003 Prescribed Burn

2002 Plant Communities

BlueOak/Grass Woodland

California Annual Grassland

California Juniper Woodland and Scrub Coastal Scrub

Disturbed

Juniper-Oak Cismontane Woodland

Mexican Elderberry Scrub

Native Grassland

Valley Oak Forest/Woodland

Fire trails

Trap lines

$0 \quad 250 \quad 500$

1,000 Feet
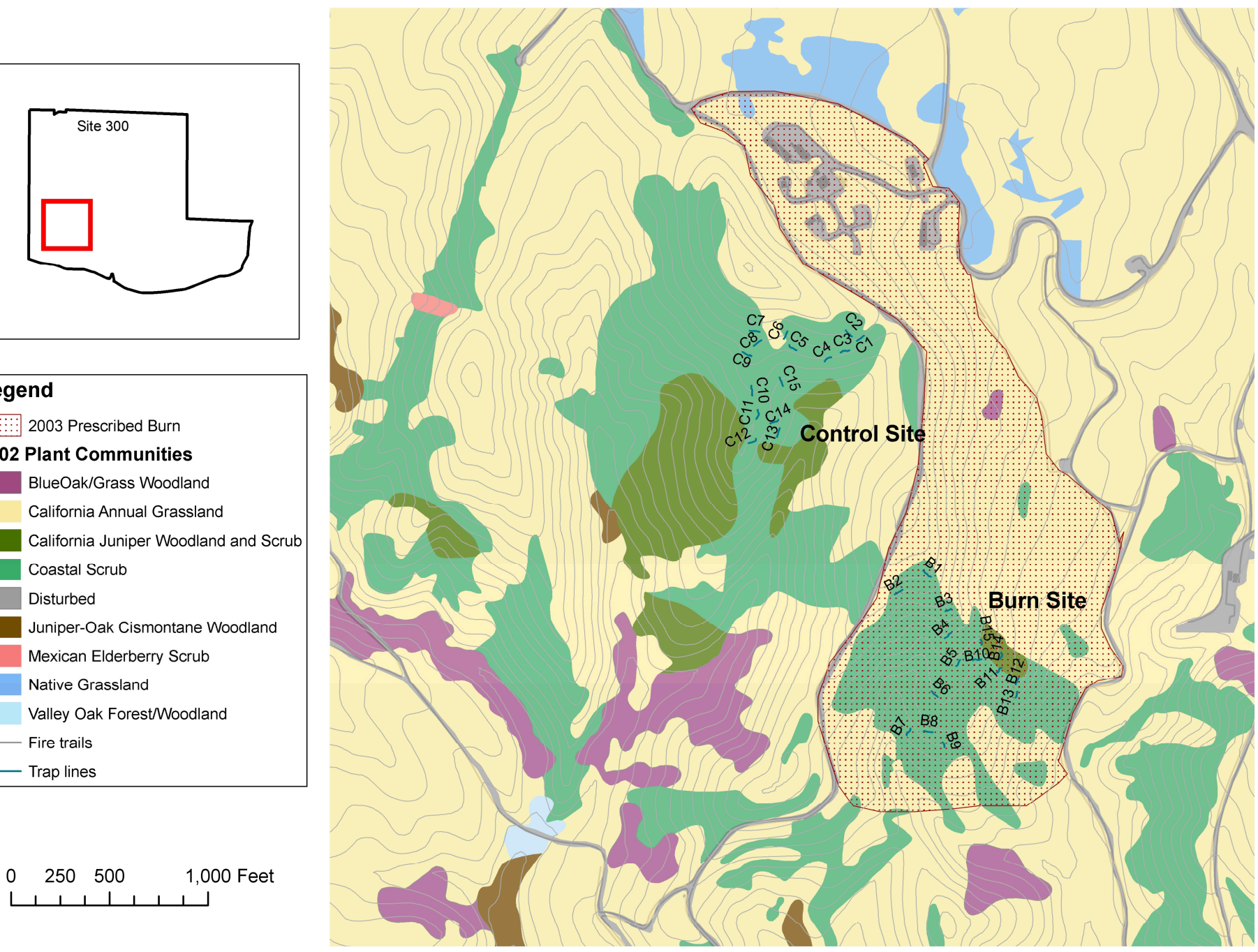

Figure 2. Location of California whipsnake trap lines and 2003 prescribed burn. 


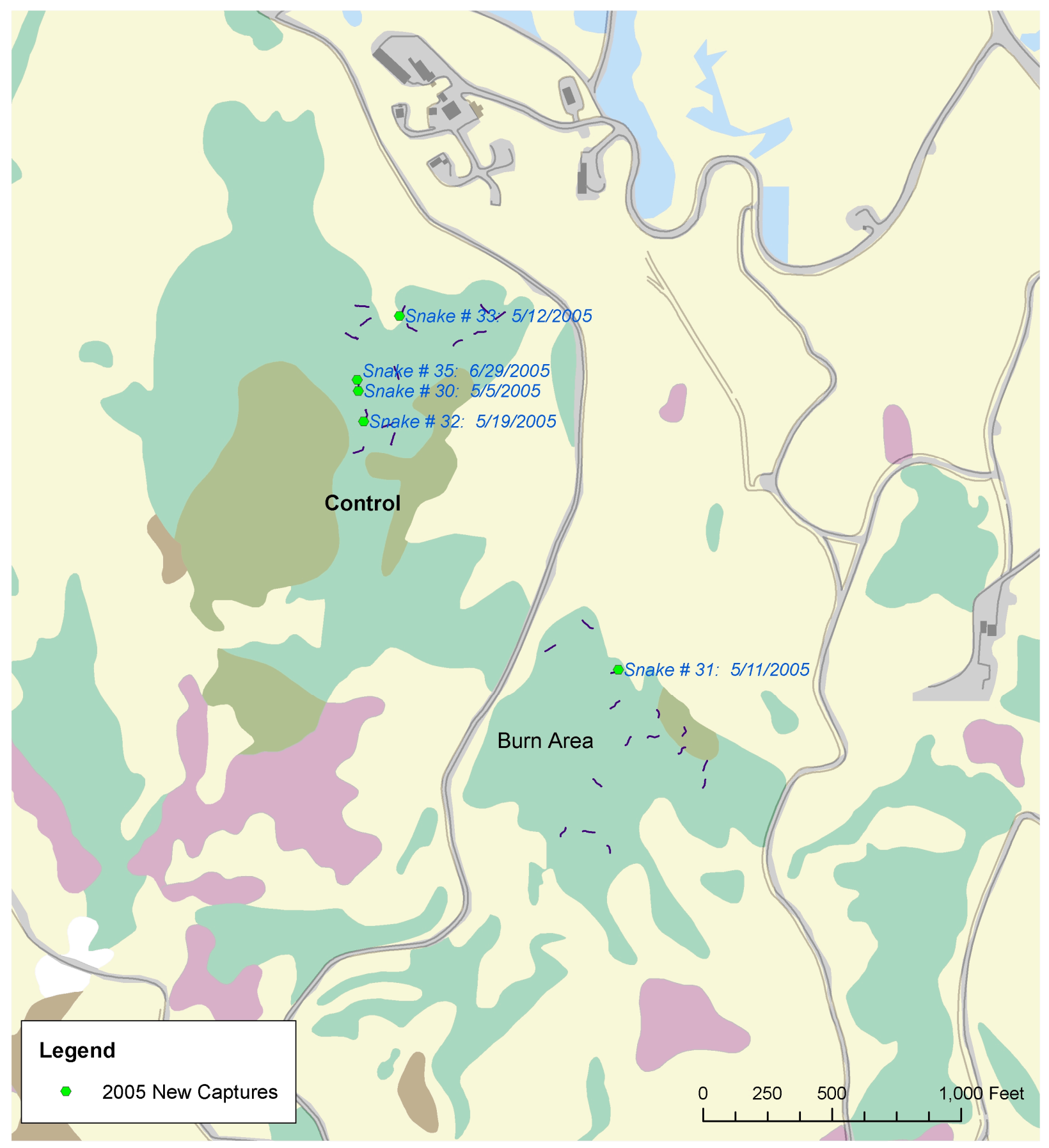

Figure 3. Location of capture for California whipsnakes that were captured for the first time in the spring of 2005. 


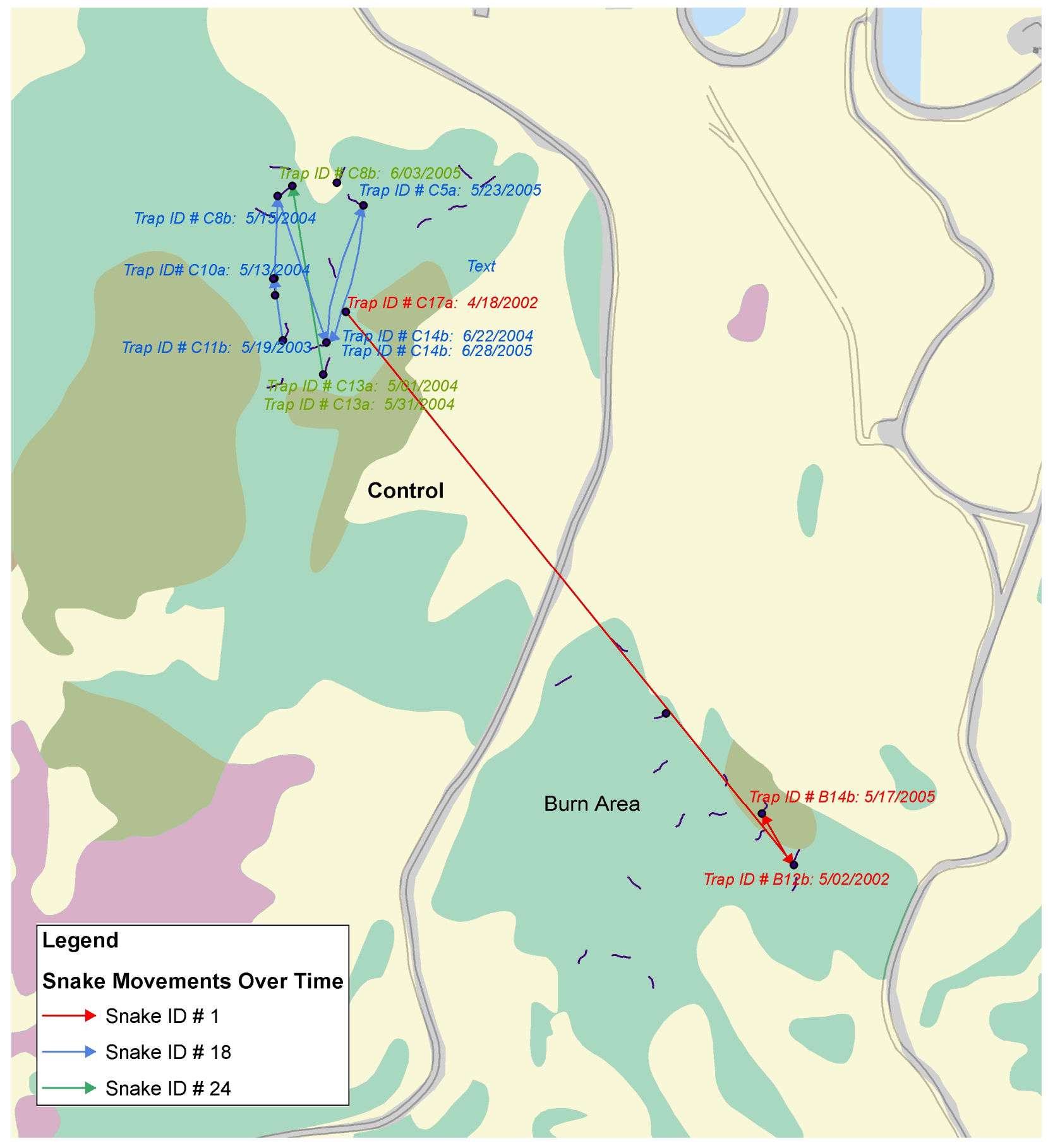

Figure 4. Locations of recaptures and movements for California whipsnakes recaptured in 2005. 


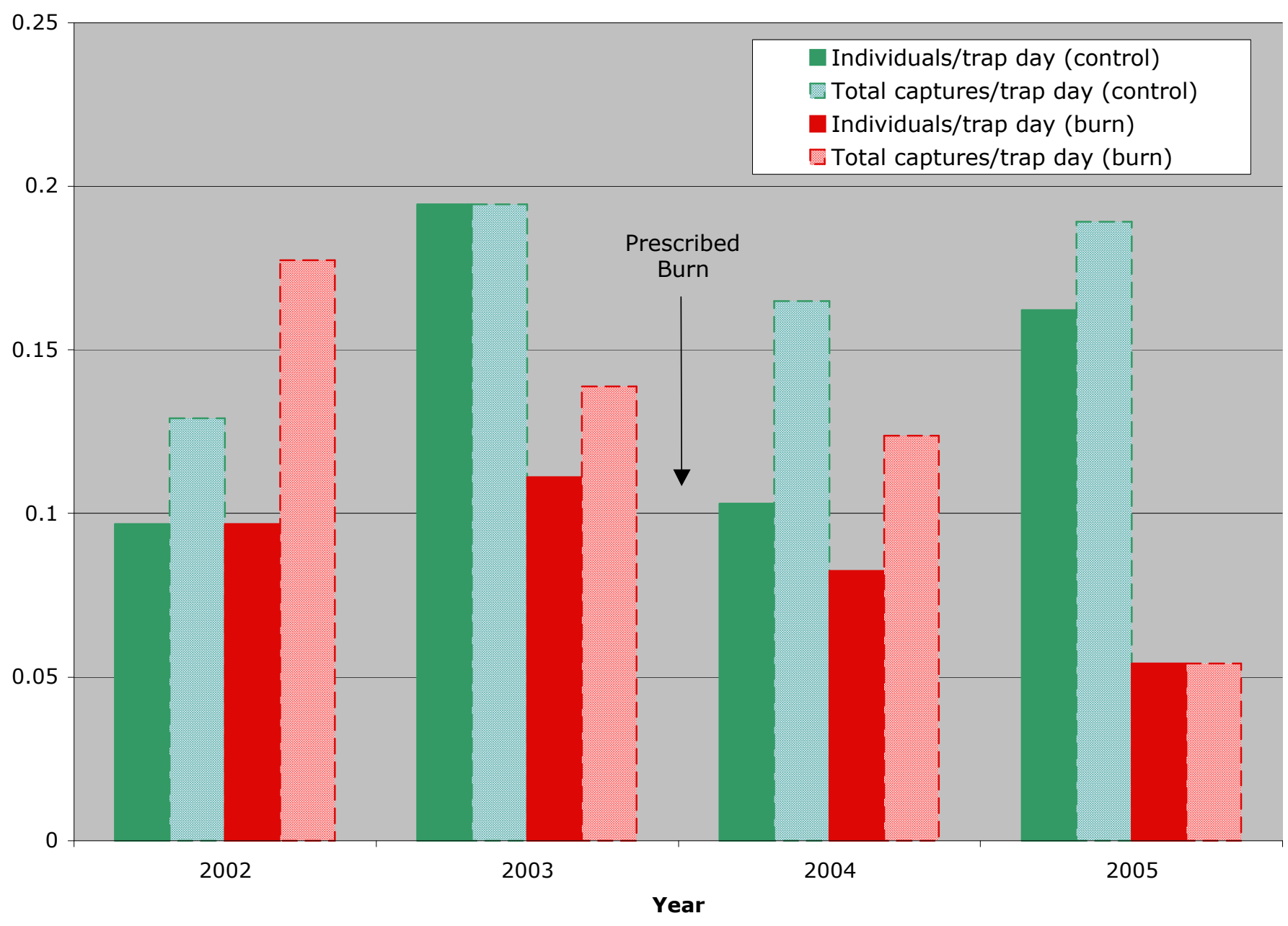

Figure 5. Capture rates for individual snakes and total captures for the spring trapping period. The number of individual snakes includes the total number of new snakes and recaptures from a pervious year captured during the trapping period, but does not include recaptures of the same individual within the trapping period. The number of total captures includes every capture of a new or recaptured snake including captures of a snake more than once during a trapping period. 


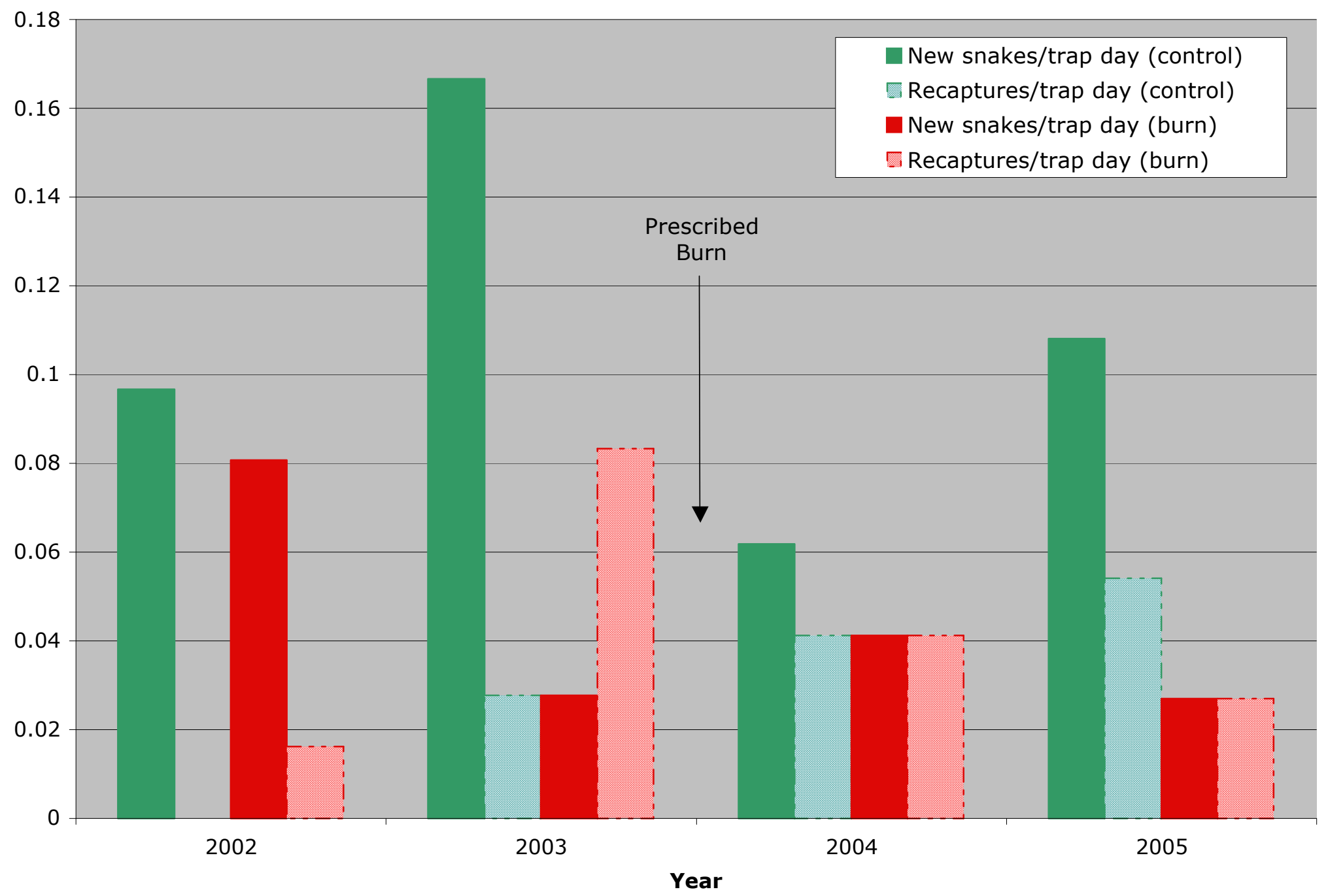

Figure 6. Capture rates for new snakes and recaptures from a previous year for the spring trapping period. These rates do not include captures of any individual more than once during the trapping period. 


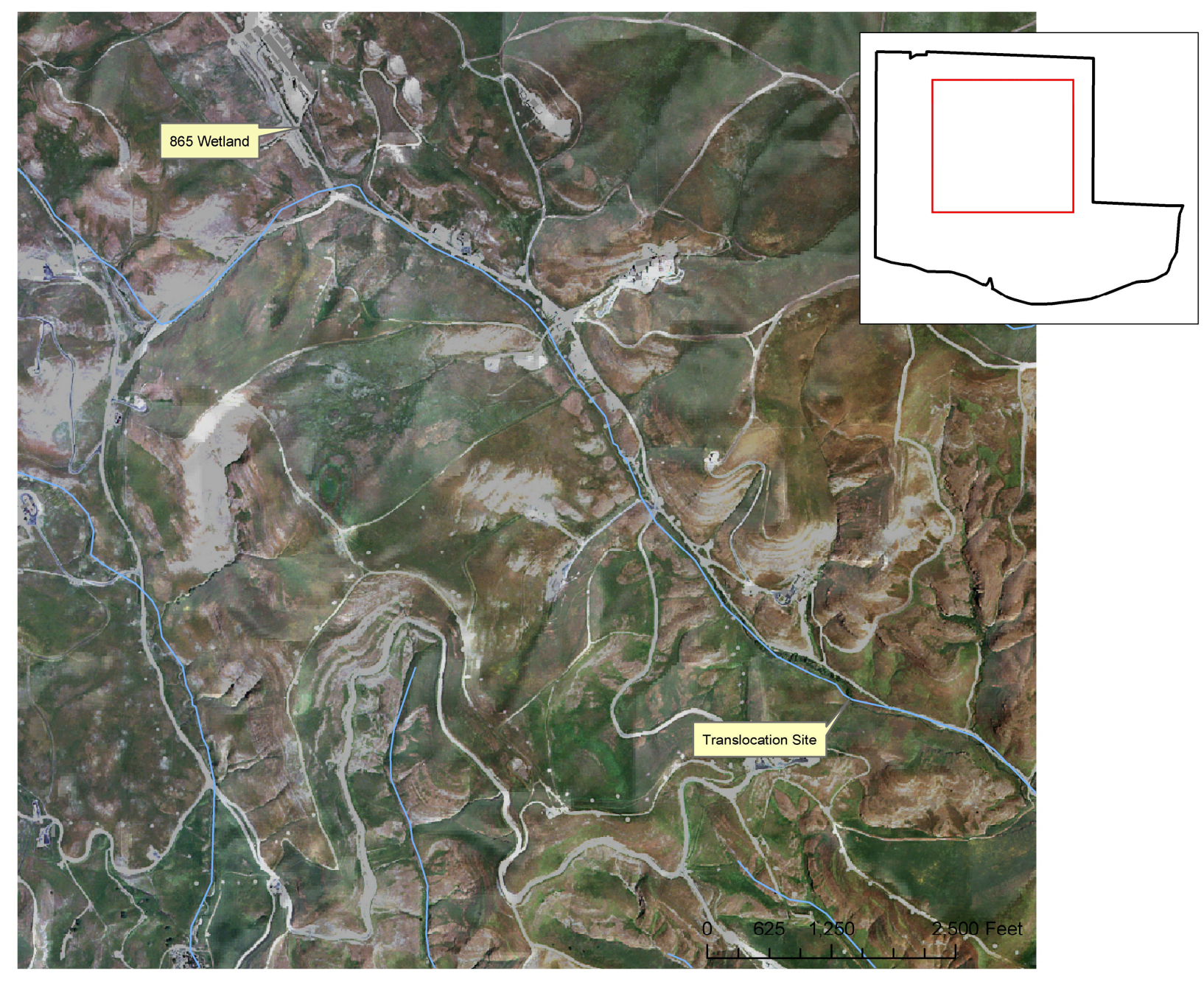

Figure 7. California red-legged frog study sites. 